\title{
GENDER DAN AKIDAH \\ (Analisa Terhadap Pekerja Perempuan di Lantebung Kelurahan Bira Kecamatan Tamalanrea Kota Makassar)
}

\author{
Anggriani Alamsyah * \\ *Dosen Ilmu Politik \\ UIN Alauddin Makassar \\ Email: anggriani.alamsyah@uin-alauddin.ac.id
}

\begin{abstract}
Abstrak:
Pekerja perempuan adalah pejuang dalam rumah tangganya, mereka tidak hanya bekerja di luar rumah, tetapi tugas utamanya sebagai ibu, tetap menunggunya di rumah. Tuntutan hidup 'memaksa' para perempuan untuk menggunakan tenaganya di luar rumah, demi memperoleh tambahan penghasilan. Penelitian ini dilakukan di wilayah Lantebung, Kota Makassar. Temuan penelitian menunjukkan bahwa meskipun perempuan hebat ini bekerja di pabrik, namun tugas untuk menjaga akidahnya dan keluarganya tetap konsisten dilakukan, ini ditunjukkan dengan tetap menjaga ibadah rutin mereka dan menyempatkan diri untuk diri untuk mendidik anak-anak mereka.
\end{abstract}

\section{Abstract:}

Women workers are fighters in their household, they don't only work outside the home, but their main task is as mothers, they are still waiting for them at home. The demands of life "force" women to use their energy outside the home, in order to earn additional income. This research was conducted in the Lantebung area, Makassar City. The research findings show that even though this great woman works in a factory, the task of maintaining her and her family's faith is consistent, this is shown by maintaining their regular worship and taking the time to educate their children.

Kata kunci: Aqidah; Ibadah; Lantebung; Perempuan; Pekerja,

\section{PENDAHULUAN}

Pada Sidang Pleno Pertemuan Tahunan International Monetary Fund (IMF) Presiden Jokowi mengajak seluruh pembuat kebijakan yang telah hadir dari berbagai belahan dunia untuk mampu menghasilkan sebuah kebijakan dan komitmen bersama untuk mengatasi permasalahan yang dapat menghambat pertumbuhan ekonomi. Kolaborasi dan kerjasama ditekankan untuk mengatasi perang dagang, capital outflow, dan penguatan dollar.

Di tengah pertemuan IMF ini pula Menteri Keuangan RI Sri Mulyani Indrawati dinobatkan sebagai Menteri Keuangan Terbaik di Asia Timur dan Pasifik Tahun 2018 versi Majalah Global Markets. Anugrah Finance Minister of The Year, 
East Asia Pacific ini diberikan atas kiprahnya mempertahankan reputasi keuangan Indonesia ditengah kondisi yang lebih menantang, saat menjabat Menkeu untuk kedua kalinya. Global Market adalah majalah berita terkemuka di bidang pasar ekonomi internasional yang 30 tahun terakhir menjadi salah satu acuan bagi para pelaku dan institusi di sector ekonomi dan keuangan internasional.

Ibu Sri Mulyani dalam Instagramnya (@smindrawati) mengemukakan bahwa kontribusi perempuan dalam bekerja memberi manfaat baik untuk keluarga, untuk ekonomi dan untuk masyarakat. Di Indonesia, tidak ada larangan bagi perempuan untuk bekerja, tetapi masih ada pandangan patrialisme di masyarakat. Wanita masih dinilai sebagai sumber kedua pencari sumber penghasilan bagi keluarga. Banyak perempuan muda yang sangat semangat saat mulai bekerja. Tetapi kemudian harus berhenti bekerja saat mulai menikah, hamil dan melahirkan. Mengurus rumah tangga dianggap sebagai tugas utama perempuan. Mereka harus membawa peran sebagai seorang Ibu, dan pekerjaan domestic dibebankan kepada perempuan.

Saat ini perempuan tidak hanya bekerja di belakang meja atau di pabrikpabrik, sebagaimana diberitakan oleh Kontan.co.id tertanggal 18 April 2018, pengemudi perempuan Indonesia untuk operator Grab, tumbuh $490 \%$ dari tahun 2017 ke tahun 2018, atau tumbuh lima kali lipat dalam setahun. Fenomena ini menunjukkan bahwa wilayah kerja yang dahulu didominasi oleh kaum lelaki, kini juga diminati oleh perempuan. Di satu sisi ini menunjukkan betapa perempuan punya kebebasan untuk memilih pekerjaan yang diinginkannya. Disisi lain menggambarkan bahwa kebutuhan ekonomi telah 'memaksa' perempuan untuk bekerja dan mencari nafkah bagi keluarganya. Selain bekerja sebagai pengemudi daring, sekarang ini banyak pula perempuan yang memanfaatkan media sosial sebagai "ladang rejeki" mereka. Dengan memanfaatkan media sosial, mereka menjual barang dagangan yang dikirimkan langsung ke rumah pembelinya, tanpa harus keluar rumah. Satu lagi pekerjaan perempuan yang patut mendapat apresiasi dan perlindungan, yakni para "pahlawan devisa" para Tenaga Kerja Perempuan (TKW) yang rela meninggalkan keluarganya di Indonesia agar mereka bisa memperoleh penghidupan yang lebih layak. Mereka inilah yang banyak menjadi korban kekerasan dalam pekerjaannya. Ekonomi dan perempuan merupakan dua 
hal yang tidak dapat dipisahkan, perempuan dapat berada di jalur formal maupun non formal.

Pentingnya memberikan perhatian kepada kesetaraan gender dalam berbagai bidang mulai mendapat perhatian dunia di tahun 1940-an, di mana perempuan dianggap warga negara kelas dua, yang kedudukannya selalu berada di belakang kaum pria.

Dalam Islam laki-laki dan perempuan mendapat porsi yang seimbang sebagaimana dalam Surah Al - Hujurat (49) : 13;

"Hai manusia, Kami telah menciptakan kamu dari laki - laki dan perempuan, dan Kami jadikan kamu berbangsa - bangsa dan bersuku- suku supaya kamu saling mengenal. Sesungguhnya yang paling mulia diantara kamu disisi Allah adalah yang paling taqwa".

Di Indonesia perempuan bekerja adalah pemandangan yang biasa, baik untuk menambah penghasilan keluarga juga karena dimotivasi oleh keinginan mencapai karir yang tinggi. Hal ini juga menjadi fenomena yang lumrah bagi warga Lantebung Kelurahan Bira Kecamatan Tamalanrea, Makassar. Umumnya perempuan-perempuan di wilayah tersebut bekerja pada salah satu pabrik di Kawasan Industri Makassar, mereka berangkat di pagi hari dan pulang di sore hari. Mereka memilih untuk bekerja di pabrik, karena jam kerja yang lebih menentu dibandingkan jika mereka harus bekerja sebagai asisten rumah tangga.

Demi memenuhi kebutuhan keluarga mereka rela menghabiskan waktunya kurang lebih delapan jam per hari bekerja di pabrik-pabrik tersebut, namun mengingat para pemilik pabrik tersebut mayoritas non muslim, menjadi pertanyaan apakah para pekerja perempuan tersebut tetap dapat melakukan ibadah lima waktu mereka sebagaimana biasa. Meskipun mereka bekerja, kewajiban untuk melakukan ibadah tidak gugur begitu saja. Mereka harus tetap memelihara nilai-nilai akidah Islam yang salah satunya mewajibkan untuk beribadah lima waktu di sela-sela waktu bekerja.

Fenomena inilah yang menarik perhatian bagi peneliti untuk ditelisik lebih jauh. Karenanya peneliti mengajukan penelitian yang berjudul "Gender dan Akidah (Analisa Terhadap Pekerja Perempuan di Lantebung Kelurahan Bira Kecamatan Tamalanrea Kota Makassar). Penelitian ini bertujuan untuk 
mengetahui hubungan pemenuhan kesetaraan gender di bidang ekonomi dengan pemeliharaan nilai-nilai akidah oleh para pekerja perempuan di Lantebung.

Beberapa tulisan terdahulu menyangkut penelitian ini antara lain: "Economic development" and gender equality: explaining variations in the gender poverty gap after socialism oleh Éva Fodor - Dániel Horn. Temuan ini mengevaluasi dampak gaya neo-liberal "pembangunan ekonomi" pada ketidaksetaraan gender secara geo-politik konteks spesifik dan menyarankan penyesuaian struktural dan integrasi pasar global memperburuk kerentanan wanita bahkan ketika mereka dilengkapi dengan modal manusia dan sumber daya lain untuk bersaing dengan pria di pasar tenaga kerja. "Peranan Perempuan Pada Pembangunan Ekonomi Dalam Perspektif Gender Di Kabupaten Badung” oleh Luh Kadek Budi Martini. Tujuan utama dari penelitian ini adalah untuk menyelidiki peran perempuan dalam ekonomi pembangunan dalam perspektif gender. Pembelajaran menemukan ketidaksetaraan gender masih terjadi pada beberapa indikator, antara lain tenaga kerja partisipasi perempuan jauh lebih rendah daripada laki-laki dalam pembangunan ekonomi. Jadi seperti itu meningkatkan peran perempuan dalam upaya pembangunan ekonomi harus dilakukan dari pihak yang terlibat, terutama pengusaha untuk memberikan peluang dan rekrutmen yang adil, pria atau wanita sesuai dengan kebutuhan. “Konstruksi Gender, Hegemoni Kekuasaan, Dan Lembaga Pendidikan" oleh Marhumah. Isu gender adalah bagian dari persoalan sosial kemasyarakatan di Indonesia, yang persoalan utamanya adalah kesenjangan mencolok antara laki-laki dan perempuan. Di dalam dunia pesantren, berdasarkan berbagai studi, menunjukkan rendahnya sensitifitas gender, berupa miskinnya perhatian pada isu perempuan dibarengi dengan dominannya figur kiai dan ustadz. Perkembangan ini mengisyaratkan menghangatnya pergesekan antara diskursus gender yang telah lama mapan dengan diskursus baru dalam proses sosialisasi gender di dunia pesantren.

Berbeda dengan tulisan-tulisan sebelumnya, penelitian ini berusaha menggambarkan bagaimana perempuan-perempuan di wilayah Lantebung memainkan perannya sebagai pekerja perempuan, tetapi tetap dapat menjaga aqidah mereka sekaligus bertanggung jawab terhadap pemeliharaan aqidah keluarganya. 


\section{TINJAUAN PUSTAKA}

1. Kesetaraan gender

Gender juga dapat dipahami sebagai konsekuensi yang timbul akibat perbedaan anatomi biologis yang mendorong munculnya aspek-aspek kebudayaan. Sebagai istilah, gender digunakan belum terlalu lama. Menurut Showalter, istilah gender mulai populer di awal tahun 1977, ketika sekelompok feminis London tidak lagi memakai isu-isu lama seperti patriarchal atau sexist tetapi menggantinya dengan wacana gender (gender discourse) Anderson dalam Marhumah (2011: 168 169). Anatomi biologis perempuan dan laki-laki yang berbeda secara alamiah membentuk kewajiban-kewajiban yang diemban mereka. Laki-laki biasanya dikondisikan untuk melakukan pekerjaan-pekerjaan berat dikarenakan fisik mereka yang lebih kekar, sementara perempuan dikondisikan untuk melakukan pekerjaan-pekerjaan yang lebih ringan. Kedudukan laki-laki pun cenderung dianggap lebih tinggi dari pada perempuan, terlebih dengan digunakannya istilah patriarki. Istilah gender yang datang belakangan lebih terdengar mewakili kesetaraan fungsi antara laki-laki dan perempuan.

Sebelum itu istilah "gender" sering digunakan secara rancu dengan istilah "seks". Sosiolog Inggris, Ann Oakley, diakui sebagai orang pertama yang membedakan istilah gender dan seks (Saptari \& Holzner dalam Marhumah, 2011: 168 - 169). Istilah seks sejatinya membedakan jenis kelamin antara laki-laki dan perempuan, istilah yang menggambarkan perbedaan secara biologis. Sementara gender merujuk kepada perbedaan pada fungsi dan peran keduanya, yang tidak didasari pada perbedaan jenis kelamin.

Gender dibentuk berdasarkan konstruksi sosial, namun justru dipandang sebagai kodrat atas ketentuan biologis. gender sendiri berarti suatu sifat yang melekat pada kaum laki-laki dan perempuan, yang dikonstruksi secara sosial dan kultural (Fakih,1997, p.7) dalam Yulidya (2014: 2). Prof. Nasaruddin Umar dalam bukunya yang berjudul Argumen Kesetaraan gender (Perspektif al-Quran) mengartikulasikan gender sebagai suatu konsep yang digunakan untuk mengidentifikasi perbedaan laki-laki dan perempuan dilihat dari segi sosial budaya. Gender dalam arti ini mendefinisikan laki-laki dan perempuan dari sudut non biologis. Istilah gender ini digunakan oleh Ivan Illich dalam membedakan 
segala sesuatu di dalam masyarakat vernacular seperti bahasa, tingkah laku, pikiran, makanan, ruang dan waktu, harta milik, tabu, alat-alat produksi, dan lain sebagainya (Mujahidah, 2010: 4).

2. Pembangunan Ekonomi

Jalur utama di mana sistem gender mempengaruhi pertumbuhan adalah dengan mempengaruhi produktivitas tenaga kerja dan efisiensi alokatif ekonomi (Bank Dunia 2002). Dalam hal produktivitas, misalnya, jika akses petani perempuan ke input produktif dan modal manusia setara dengan akses laki-laki, total pertanian output dapat meningkat sekitar 6 hingga 20 persen (World Bank 2001b). Istilah dari efisiensi alokatif, sementara peningkatan pendapatan rumah tangga umumnya dikaitkan dengan mengurangi risiko kematian anak, dampak marjinal hampir 20 kali lebih besar jika penghasilan ada di tangan ibu daripada ayah (WBGDG 2003). Identifikasi perempuan sebagai tenaga kerja yang dapat diandalkan, produktif, dan murah. Mereka adalah tenaga kerja pilihan untuk tekstil dan perusahaan transnasional elektronik. Persepsi wanita sebagai 'baik dengan uang', termasuk menjadi lebih baik dalam membayar kembali pinjaman, telah mengarahkan mereka untuk ditargetkan dalam program keuangan mikro. Pengakuan perempuan karena distributor barang dan jasa yang lebih efisien dalam rumah tangga telah membawa mereka ditargetkan dengan sumber daya yang ditujukan untuk mengurangi kemiskinan, seperti transfer uang tunai program (Bradshaw, 2013: 5).

Hasil yang sejalan ditemukan oleh penelitian yang mengambil sampel di 127 negara oleh Garcia et.al (2018: 1) menggambarkan hubungan pertumbuhan ekonomi dan faktor-faktor gender: pendidikan, akses ke lapangan pekerjaan, fertilitas, dan demokrasi. Penelitian ini menyimpulkan bahwa fertilitas perempuan mempunyai efek negatif pada pertumbuhan ekonomi. Namun, ketika perempuan mempunyai akses yang lebih besar kepada pendidikan sekunder dan pasar kerja dalam kondisi setara, efeknya positif. Demikian halnya, akses perempuan terhadap partisipasi politik aktif mempunyai efek signifikan pada pertumbuhan ekonomi. Keseluruhan, penelitian ini membantu mengidentifikasi faktor gender mana yang meningkatkan pertumbuhan ekonomi inklusif, dimana pertumbuhan ekonomi tercapai ketika laki-laki dan perempuan menyatu dalam kondisi setara. 
Dampak faktor gender pada pertumbuhan ekonomi pada negara yang berbeda. Untuk mendefinisikan pertumbuhan ekonomi dari perspektif inklusif, kami mendefinisikan istilah "pertumbuhan ekonomi inklusif" untuk pertama kalinya dalam literatur. Pertumbuhan ekonomi inklusif bermakna bahwa upaya untuk pertama kalinya dalam literatur. Pertumbuhan ekonomi yang inklusif berarti bahwa upaya untuk memajukan pertumbuhan dan pembangunan suatu negara harus dihasilkan dengan kontribusi semua warga negara tanpa mengecualikan kelompok masyarakat yang penting, lebih khusus lagi, perempuan. Mempertimbangkan penilaian bahwa "kesetaraan jender membawa pertumbuhan ekonomi tetapi pertumbuhan ekonomi tidak serta merta menghasilkan kesetaraan jender" [1], kami fokus pada faktor jender yang memicu peningkatan dan merangsang pertumbuhan ekonomi di suatu negara, baik untuk rendah maupun tinggi. negara-negara berpenghasilan, dan dengan demikian menghasilkan pertumbuhan ekonomi yang inklusif (Garcia, 2018: 1).

Melihat kenyataan bahwa Indonesia adalah negara dengan penduduk mayoritas muslim, maka peneliti menambahkan satu lagi pendekatan untuk melihat pembangunan ekonomi dan perempuan, yakni pendekatan akidah. Pendekatan ini melihat peran perempuan di bidang ekonomi dari sudut pandang keagamaan. Apakah peran mereka didasarkan semata karena menambah penghasilan atau untuk mendekatkan diri kepada Allah SWT.

3. Aqidah

Sedangkan „aqidah menurut bahasa Arab (etimologi) berasal dari ‘aqadaya`qidu-'uqdatan wa `aqidatan artinya ikatan atau perjanjian. Kata al-'aqdu yang berarti ikatan, at - tautsi qu yang berarti kepercayaan atau keyakinan yang kuat, al - ihkamu yang artinya mengokohkan (menetapkan), dan ar - rabt\} u bi quwwah yang berarti mengikat dengan kuat (Yazid bin Abdul Qadir Jawas, dalam repository.radenintan.ac.id diakses 20 Januari 2019). Secara terminologi, 'aqa'id ialah jamak dari aqidah (credo), artinya kepercayaan. Yaitu sesuatu yang mengharuskan hati membenarkannya, yang membuat jiwa tenang tentram kepadanya, dan yang menjadi kepercayaan/keyakinan yang bersih dari bimbang dan ragu (Suyatno Prodjodikoro, dalam repository.radenintan.ac.id diakses 20 Januari 2019). Menurut Hasan al-Banna 'aqa'id adalah: Beberapa perkara yang 
wajib diyakini kebenarannya oleh hatimu, mendatangkan ketentraman jiwa, menjadi keyakinan yang tidak bercampur sedikitpun dengan keragu-raguan. Sedangkan menurut Abu Bakar Jabir al-Jazairy mengatakan akidah adalah: Yaitu sejumlah kebenaran yang dapat diterima secara umum oleh manusia berdasarkan akal, wahyu, dan fitrah. Kebenaran itu dipatrikan di dalam hati dan diyakini kesahihan dan keberadaannya secara pasti, dan ditolak segala sesuatu yang bertentangan dengan kebenaran itu (Suyatno Prodjodikoro, dalam repository.radenintan.ac.id diakses 20 Januari 2019).

Sedangkan ulama" fiqh mendefinisikan akidah sebagai berikut: Akidah ialah sesuatu yang diyakini dan dipegang teguh, sukar sekali untuk diubah. Ia beriman berdasarkan dalil-dalil yang sesuai dengan kenyataan, seperti beriman kepada Allah Swt. para Malaikat Allah, Kitab-kitab Allah, dan Rasul-rasul Allah, adanya kadar baik dan buruk, dan adanya hari akhir (Muhammad Abdul Qadir Ahmad, dalam repository.radenintan.ac.id diakses 20 Januari 2019).

Ruang lingkup 'aqidah dapat diperinci sebagaimana yang dikenal sebagai rukun iman, yaitu iman kepada Allah, malaikat (termasuk didalamnya: jin, setan, dan iblis), kitab-kitab Allah yang diturunkan kepada para utusan-Nya, Nabi dan Rasul, hari akhir, dan takdir Allah (Hasan Al-Banna, dalam repository.radenintan.ac.id diakses 20 Januari 2019). Beriman Kepada Allah Beriman kepada Allah mengandung pengertian percaya dan meyakini akan sifatsifat-Nya yang sempurna dan terpuji. Dasar-dasar kepercayaan ini digariskan-Nya melalui rasul-Nya, baik langsung dengan wahyu atau dengan sabda rasul (Zakiah Darajat dalam repository.radenintan.ac.id diakses 20 Januari 2019).

\section{METODE PENELITIAN}

Penelitian ini menggunakan metode penelitian kualitatif, yaitu suatu metode penelitian yang digunakan untuk meneliti pada kondisi obyek yang alamiah dimana peneliti adalah instrument kunci. Teknik pengumpulan datanya dilakukan dengan cara triangulasi (gabungan), analisis ini data bersifat induktif dan hasil penelitian lebih menekankan makan dari generalisasi (Sugiyono, 2008: 11). Metode ini digunakan dalam melihat fenomena yang terjadi dilapangan yang menyangkut keseteraan gender dalam bidang ekonomi dan apakah keterlibatan 
pekerja perempuan warga Lantebung di bidang ini memungkinkan mereka untuk tetap memelihara akidahnya. Wawancara ditujukan untuk memperoleh keterangan untuk tujuan penelitian dengan cara tanya jawab sambil bertatap muka antara pewawancara dan informan atau orang yang diwawancarai, dengan atau tanpa menggunakan pedoman wawancara (Bungin, 2011: 111). Peneliti akan mewawancarai beberapa warga perempuan dan laki-laki Lantebung untuk memperoleh informasi apakah keterlibatan perempuan Lantebung di bidang ekonomi, tidak mempengaruhi akidah mereka. Panca indra merupakan alat utama observasi dalam mendukung data-data lainnya. Peneliti mengumpulkan data dari berbagai dokumen resmi yang sesuai dengan obyek dari penelitian ini. Juga literature yang ada hubungannya dengan focus penelitian ini (Bungin, 2011: 114). Penelitian ini menggunakan analisa kualitatif QDA Miner Lite berdasarkan data yang diperoleh agar diperoleh hasil yang menggambarkan kesetaraan gender yang berlaku di Lantebung dan apakah dengan hal tersebut, mereka tetap bisa menjaga akidahnya.

\section{HASIL DAN DISKUSI}

1. Industrialisasi dan Pekerja Perempuan

Peradaban umat manusia mengalami perubahan yang dahsyat dalam sejarah mutakhir. Dimulai di Eropa dengan Renaissance pada abad XIV yang diawali dengan gerakan kebudayaan mencakup berbagai kesenian yang hidup di masyarakat sebagai penggerak dinamika perkembangan zaman. Berbagai pandangan baru dan penemuanpenemuan empiris ilmu pengetahuan membongkar berbagai kemapanan tradisi. Berbagai penemuan yang mendasari peradaban baru, cukup mencengangkan masyarakat pada zamannya saat itu, sehingga sempat terjadi pula berbagai ketegangan dan perseteruan faham dikalangan para penganut tradisi lama dan penemu baru. Berbagai penemuan baru tersebut menggerakkan masyarakat yang selama ini dibawah kungkungan kegelapan dogma, seperti memperoleh pencerahan (Baiquni, 2009).

Dalam catatan sejarah, berbagai penemuan spektakuler membuat para ilmuwan berambisi selalu mengungguli yang lain. Pada 1769 James Watt dicatat sebagai pembuat mesin uap hasil penyempurnaan temuan para ilmuwan sebelumnya. Penemuan ini dianggap tonggak yang memicu revolusi industri. Berbagai mesin dikembangkan 
dengan basis mesin uap untuk menggerakkan kapal, kereta api dan mobil. Mesin-mesin industri juga bermunculan untuk mengolah sumberdaya alam dan bahan mentah menjadi bahan jadi secara masal yang disebut industri. Penemuan-penemuan ini merubah pola kehidupan manusia yang semula mengandalkan tenaga hewan dan manusia untuk melakukan produksi, transportasi dan kegiatan hidup lainnya, menjadi mengandalkan mesin (Baiquni, 2009).

Seiring dengan penemuan dalam bidang teknik dan rekayasa yang ditandai dengan pengembangan mesin-mesin modern dan munculnya industri skala besar, berkembang pula ilmu ekonomi. Pada tahun 1776, Adam Smith mengemukakan pendapat dan berdebat tentang ekonomi pasar bebas dan melahirkan atau dianggap sebagai awal dari ilmu ekonomi. Dasar awal Ilmu Ekonomi yang lahir pada 1776 populer dengan nama pada awalnya sebagai ekonomi politik (Mubyarto, 1987) dalam Baiquni (2009).

Dengan semakin berkembangnya industry, maka lapangan kerja juga semakin terbuka lebar. Ini tentu berdampak pada beragam hal. Semisal pesatnya arus urbanisasi, para petani pekerja, petani yang tidak punya lahan, lebih memilih untuk bermigrasi ke kota karena mereka menganggap bekerja di pabrik lebih punya nilai kepastian, mereka datang pukul delapan pulang pukul lima sore dan di awal bulan menerima gaji, lebih mereka cintai daripada bekerja mengolah lahan pertanian yang tidak pasti pendapatannya. Mereka umumnya tidak punya keterampilan khusus, dikarenakan bekerja di pabrik memang tidak butuh itu. Pekerjaan mereka boleh dikatakan dari pagi sampai sore hanya semacam saja, dan jika itu dilakukan berulangkali, maka mahirlah mereka. Kesempatan kerja tidak hanya terbuka lebar buat kaum lelaki tetapi juga bagi kaum perempuan, banyak jenis pekerjaan di pabrik yang dianggap lebih rapih hasilnya jika dikerjakan oleh buruh perempuan.

Seiring perkembangan yang terjadi, Indonesia tidak terlepas dari perkembangan industri yang sedikit demi sedikit menggerus lahan-lahan pertanian yang ada. Wilayah yang dulunya masih masuk wilayah pedesaan dengan wilayah pertaniannya, pelan-pelan berubah menjadi daerah pinggiran kota, karena pabrik-pabrik telah dibangun menggantikan sawah-sawah. Belum lagi, warga pedesaan yang dulunya bangga menjadi petani, pelan-pelan berubah menjadi rasa minder. Mereka lebih bangga menjadi buruh pabrik, yang bekerja dengan jam tertentu dengan pakaian yang rapih. 
Dibandingkan dengan bekerja di sawah, penuh lumpur, disengat matahari, dimana tenaga yang dikeluarkan lebih besar. Kebanggaan menjadi petani bertransformasi menjadi kebanggaan sebagai buruh pabrik.

Indonesia sebagai negara berkembang juga tidak luput dari virus industrialisasi tersebut. Semenjak pembangunan ekonomi di mulai secara terencana sejak tahun 1969, sesungguhnya pendekatan yang digunakan adalah strategi industrialisasi. Terdapat dua pertimbangan penting yang melandasi strategi industrialisasi tersebut. Pertama, pada tahun-tahun tersebut negara-negara di seluruh dunia juga mengerjakan proyek industrialisasi di negaranya masing-masing dengan dukungan teori-teori ekonomi pembangunan yang memadai. Kedua, sejarah Negara-negara yang berhasil memajukan ekonominya selalu melewati tahapan industrialisasi pada proses pembangunannya. Strategi ini dianggap berhasil karena secara perlahan-lahan menggeser kegiatan ekonomi dari semula terkonsentrasi pada sector primer (pertanian) menuju sector sekunder (industry/jasa) dalam Hakim (No Date: 1-2).

Lantebung sebenarnya masuk wilayah Kota Makassar, menuju ke area ini kita harus melewati samping jalan tol. Perjalanan dapat ditempuh kurang dari 30 menit jika start dari Jalan Yos Sudarso. Di sekitar wilayah ini ada perusahaan milik Kalla Group, Bosowa Group dan tempat penyimpanan gas LPG Pertamina. Wilayah ini masuk dalam program Corporate Social Responsibility Pertamina. Ini dibuktikan oleh papan penanda Pertamina sebelum kita berbelok kiri masuk ke wilayah Lantebung. Berbagai program telah dilaksanakan oleh pertamina antara lain, penanaman mangrove, penangkaran kepiting, dan bank sampah.

Peneliti menemukan bahwa penduduk di sana tidak begitu tertarik untuk melanjutkan pendidikan di tingkat sarjana, karena mereka melihat beberapa warga mereka yang sarjana, tidak memiliki pekerjaan yang sesuai dengan tingkat pendidikan mereka. Di wilayah ini terdapat empang yang mengembangbiakkan kepiting, yang juga menjadi salah satu mata pencaharian warga Lantebung. Lantebung juga wilayah yang dekat dengan Kawasan Industri Makassar, membuat masyarakat sekitar tertarik untuk bekerja disana.Salah satu alasan mereka bekerja adalah menambah penghasilan, jika menilik rumah-rumah yang berada di wilayah Lantebung maka kita bisa melihat bahwa tingkat kehidupan mereka cukup sederhana. Jikalaupun rumah mereka rata-rata terbuat 
dari batu merah, namun jarang yang bertingkat dua, bahkan masih ada yang menempati rumah kayu.

Pekerja yang berasal dari wilayah Lantebung tidak hanya laki-laki, bahkan banyak perempuan yang juga mencari tambahan rejeki di PT. Kima. Mereka memilih untuk bekerja di sana daripada bekerja sebagai asisten rumah tangga misalnya, dikarenakan jam kerja yang maksimal hanya 10 jam dengan sistem shift. Salah satu faktor yang memungkinkan para wanita tersebut bekerja dikarenakan anak-anak mereka telah beranjak remaja, sehingga tidak lagi butuh perhatian sebanyak ketika mereka masih kecil. Dengan bekerja di salah satu pabrik, terlihat bahwa mereka sudah mampu memenuhi beberapa kebutuhan tersier mereka, misalnya membeli kendaraan bermotor. Salah satu wawancara dengan Sdri NW, antara lain:

Saya bekerja untuk menambah penghasilan, pekerjaaan saya di pabrik tersebut adalah sebagai pengawas. Saya bekerja selama 10 jam dengan sistem 2 shift, hari ahad kami mendapatkan libur, ketika hari raya saya tidak mendapat bingkisan. Namun saya tetap mempersiapkan keperluan rumah tangga sebelum berangkat bekerja. Nilai-nilai yang dipunyai di pekerjaan saya adalah keihklasan, ikhlas, dan disiplin. Pekerjaan ini cukup membantu perekonomian keluarga.

Pada Garis-Garis Besar Haluan Negara tahun 1978 atau 50 tahun setelah Kongres Wanita Indonesia (KOWANI) I yang sekaligus diikuti oleh Kementrian Urusan Peranan Wanita. Oleh karena itu, saat ini secara normatif baik dalam UUD 1945 dan GBHN 1978 sampai GBHN 1999 dan RPJM saat ini telah tercantum adanya hak, kewajiban dan kesempatan yang sama antara kaum laki-laki dan perempuan dalam segala aspek pembangunan. Disamping itu pemerintah juga telah meratifikasi konvensi ILO No. III dengan UU No. 80 tahun 1957 tentang pengupahan yang sama antara laki-laki dan perempuan dalam jenis pekerjaan yang sama nilainya dan juga telah meratifikasi konvensi tentang penghapusan segala bentuk diskiriminasi terhadap perempuan (CEDAW) dengan UU No. 7 tahun 1984 (Martini, 2015).

Para perempuan ini bertahan untuk bekerja walaupun harus meninggalkan keluarganya karena mereka merasa dapat mereka punya waktu yang cukup untuk bekerja sambil mendampingi keluarganya, karena sistem yang diberlakukan adalah sistem shift. Bagi perempuan yang bekerja di pabrik, umumnya bukanlah pekerjaan kasar, umumnya mereka bekerja di bagian pengepakan yang sebenarnya tidak memerlukan keterampilan khusus. Gaji yang diperoleh lumayan, dengan jam kerja yang jelas, membuat banyak orang meminati pekerjaan tersebut. 
Dari sekitar 265 tenant di Kawasan Industri Makassar, nyaris setengahnya adalah industri makanan. Di pabrik-pabrik inilah, misalnya mie dan coklat, para perempuanperempuan Lantebung bekerja. Di pabrik-pabrik ini mereka nyaris tidak melakukan pekerjaan yang terlalu berat, karena tiap orang punya tugas sendiri yang telah terspesialisasi. Misalnya, satu orang tugasnya hanya memperbaiki susunan mie yang akan dikemas dalam dus, pekerja lainnya hanya bertugas memasukkan bahan baku mie ke pengadon. Mereka adalah pekerja-pekerja terlatih untuk spesialisasi pekerjaan tertentu.

Selain jenis pekerjaan yang tidak membutuhkan tenaga dan keahlian yang beragam, pekerjaan ini dianggap mempunyai system penggajian yang cukup memuaskan sehingga pekerjaan ini dapat membantu perekonomian keluarganya. Perempuan di Indonesia termasuk perempuan yang beruntung, karena mereka dapat bekerja di bidang apapun yang mereka inginkan, selama mereka mampu. Kita sering melihat perempuan menjadi tukang batu, untuk memenuhi kebutuhan keluarganya, sampai presiden.

Bekerja bagi perempuan tidak selalu sebagai sebuah kewajiban, sebagian perempuan bekerja semata karena mereka senang dengan pekerjaan tersebut, karena pekerjaan itu memicu kreatifitasnya. Ada pula perempuan yang bekerja karena mereka ingin punya karir setinggi-tingginya yang bisa mereka capai, sebagai pembuktian kompetensi mereka. Adapula yang bekerja semata karena ingin membantu perekonomian keluarga, tetapi tidak diwajibkan oleh pasangannya. Ada pula yang bekerja karena memang roda perekonomian keluarganya tidak akan berjalan dengan baik jika mereka tidak berkerja. Adapula perempuan yang berkerja karena dia adalah orang tua tunggal yang memang harus bekerja untuk menghidupi diri dan anak-anaknya.

Akan hanya untuk perempuan-perempuan di Lantebung, umumnya mereka bekerja, selain untuk menambah pendapatan rumah tangga, mereka juga bekerja karena anak-anak mereka sudah cukup besar yang menurut mereka tidak perlu lagi di beri perlakuan khusus seperti ketika mereka masih balita. Anak-anak ini rata-rata sudah duduk di bangku SD dan dianggap cukup mampu mengurusi dirinya sendiri, hingga orang tuanya datang dari pabrik.

"Saya bekerja karena anak-anak sudah besar dan untuk membantu perekonomian keluarga. Pihak perusahaan cukup perhatian dengan memberikan parcel hari raya 
dan saya masih sempat keperluan keluarga sebelum berangkat bekerja" (Wawancara dengan Sng, 46 tahun).

Peneliti, belum berani menyatakan apakah hal ini disadari oleh buruh perempuan atau tidak, karena selama ini nyaris belum terdengar "suara" buruh yang terkesan sexist, maksud memperjuangkan ketimpangan upah laki-laki dan perempuan, yang ada hanyalah tuntutan untuk menaikkan upah minimum.

2. Tanggung Jawab Akan Pendidikan Anak

Orang tua adalah pembentuk awal karakter anak-anaknya, bahkan sebelum mereka lahir. Sejak pemilihan pasangan hidup, sebenarnya awal pembentukan karakter anak-anak kita. Islam memberikan tuntunan untuk memilih pasangan hidup didasari empat alasan: wajahnya, hartanya, keturunannya dan agamanya, dan memilih berdasarkan agama adalah yang paling utama. Alangkah bahagianya jika berkumpullah keempatnya. Pasangan yang memiliki ciri-ciri di atas (pengutamaan ada pada agama) merupakan proses awal pembentukan karakter anak-anak, pasangan yang baik dalam pandangan agama tentu akan menurunkan nilai-nilai baik ke pada anak-anak keturunannya. Sebagaimana sabda Rasulullah saw,

Tiada seorangpun yang dilahirkan kecuali dilahirkan pada fithrah (Islam)nya. Kedua orang tuanyalah yang menjadikannya Yahudi, Nasrani atau Majusi. [HR. al-Bukhâri dan Muslim][1]

Makna hadits di atas adalah manusia difitrahkan (memiliki sifat pembawaan sejak lahir) dengan kuat di atas Islam. Akan tetapi, tentu harus ada pembelajaran Islam dengan perbuatan/tindakan. Siapa yang Allah subhanahu wa ta'ala takdirkan termasuk golongan orang-orang yang berbahagia, niscaya Allah subhanahu wa ta'ala akan menyiapkan untuknya orang yang akan mengajarinya jalan petunjuk sehingga jadilah dia dipersiapkan untuk berbuat (kebaikan). Sebaliknya, siapa yang Allah subhanahu wa ta'ala ingin menghinakannya dan mencelakakannya, Allah subhanahu wa ta'ala menjadikan sebab yang akan mengubahnya dari fitrahnya dan membengkokkan kelurusannya. Hal ini sebagaimana keterangan yang ada dalam hadits tentang pengaruh yang dilakukan kedua orang tua terhadap anaknya yang menjadikan si anak beragama Yahudi, Nasrani, atau Majusi (Media Online Asy-Syariah edisi 070 diakses 21 Oktober 2018).

Dari sini terlihat bahwa peran orang tua sangat penting membentuk pribadi seorang anak. Orang tua harus mulai memberikan pendidikan agama kepada anak- 
anaknya sejak mereka dalam kandungan, dengan memperdengarkan ayat-ayat al-Quran misalnya, sehingga nilai-nilai keislaman mulai tertanam sejak mereka dalam kandungan. Kerjasama yang baik antara suami dan istri untuk mendidik anak turut menentukan kualitas karakter anak-anak mereka. Suami dan istri harus dapat memberikan perhatian yang proporsional kepada anak-anak mereka, perhatian mereka merupakan kekuatan yang saling melengkapi, jika salah satu kurang, maka hasilnya juga tidak bisa maksimal, karena peran mereka berbeda-beda.

Belajar ilmu agama adalah kewajiban setiap muslim, ketika belum baliq tanggung jawab pendidikan agama anak berada di tangan orang tuanya. Meskipun orang tua bekerja, namun mereka harus tetap memperhatikan pendidikan agama anakanaknya, karena di hari penghisaban kelak, mereka akan dimintai pertanggungjawaban atasnya. Pendidikan agama yang utama ada di rumah, pendidikan agama disekolah hanyalah pelengkap semata.

Wawancara dengan para ibu pekerja di Lantebung juga cukup memperhatikan pendidikan kepada anak-anak mareka. Diantaranya ada yang mengatakan bahwa keluarga adalah hal yang utama, sebelum mereka berangkat kerja, mereka mempersiapkan keperluan keluarganya. Waktu kerja mereka juga tidak sampai pukul 18:00, karenanya mereka masih sempat mengajarkan nilai-nilai kehidupan yang mereka anggap penting bagi masa depan anak-anaknya. Di antara nila-nilai tersebut adalah kerja keras, kejujuran, tanggung jawab, rajin, disiplin, dan kesabaran. Nilai-nilai ini mereka lisankan, dan juga dicontohkan dalam kehidupan mereka sehari-hari.

Hadist yang diriwayatkan Abu Hurairah R.A bahwa Rasulullah SAW "Barang siapa yang tidak mengasihi (anaknya), maka dia tidak dikasihi (anaknya)". Bisa diartikan bahwa jika orang tua ingin anaknya menjadi pengasih, maka dia harus mencontohkannya terlebih dahulu. Kita tentu familiar dengan kisah ketika suatu hari Rasulullah sedang mengimani shalat di masjid Nabawi, dan beliau sujud untuk waktu yang cukup lama, sampai-sampai sahabat bertanya apakah Baginda Nabi sakit atau semisalnya. Tapi setelah bangun dari sujud, sadarlah mereka apa yang sedang terjadi, Hasan dan Husain, cucu Baginda SAW sedang berada di punggung beliau dan tidak ingin mengganggu kesenangan mereka. Ini menjadi pelajaran bagi kita, bahwa penanaman iman harus sejak awal, dengan rajin membawa anak-anak ke masjid, membimbing mereka melakukan ibadah, semampu mereka, karena anak-anak memang 
kesenangannya bermain, tetapi dikarunia rasa ingin tahu yang besar. Karenanya, rasa ingin tahu tersebut harus dalam bimbingan orang tuanya, dengan memperkenalkan mereka dengan ilmu agama sejak dini.

Era millennium memungkinkan informasi berpindah dengan sangat cepat dan mudah, dibarengi dengan akses yang instan pula. Dunia ada di genggaman tangan, nyaris apapun yang kita butuhkan bisa diakses dengan jaringan internet yang memadai. Sayangnya, tidak hanya hal-hal positif yang bisa diakses dengan mudah, konten-konten negative yang dibuat oleh manusia-manusia tak bermoral, juga dapat diakses dengan cepat. Orang tua seharusnya menjadi benteng terdepan atas penjagaan moral anak-anak mereka, yang seharusnya dimulai sejak mereka berada dalam kandungan. Kita sebagai orang tua tidak boleh hanya menyerahkan tanggung jawab ini kepada sekolah, karena waktu terbanyak anak-anak tentu saja di rumah mereka. Jadi orang tua hendaklah lebih peduli atas pembentukan moral anak-anak mereka. Anak-anak yang diberi contoh akhlak yang baik, tentu akan meniru itu dikesehariannya kepada orang-orang disekelilingnya. Bila akhlak yang baik sudah tertanam dengan baik di rumah, maka, orang tua telah memberikan sumbangsih bagi komunitas yang lebih besar.

Ketika peneliti bertanya apakah dengan bekerjanya ibu maka itu membatasi waktu dengan keluarga, maka jawaban yang penulis peroleh terbagi dua. Ada yang menjawab terbatasi tapi ada pula yang menjawab tidak terbatasi. Meskipun ada yang menjawab terbatasi, namun itu tidak menyurutkan niat mereka untuk bekerja. Hal ini dikarenakan dengan bekerja mereka dapat menambah pendapatan keluarga. Keluarga tetap merupakan prioritas utama mereka.

Dari uraian di atas menunjukkan tidak ada alasan bagi ibu yang bekerja untuk tidak memberikan kasih sayang kepada anak-anaknya, demikian pula memperhatikan pendidikannya terutama pendidikan agama. Hal ini dibuktikan oleh ibu-ibu dari Lantebung yang mengatakan keluarga bagi mereka tetap nomer satu, dan mereka selalu meluangkan waktu untuk keluarganya sebelum dan sesudah dari tempat bekerja, juga ketika dimasa-masa libur mereka.

3. Pekerja Perempuan dan Akidahnya

Hak pekerja Perempuan mengatur hak cuti hamil dan melahirkan, cuti keguguran, biaya persalinan, cuti menstruasi, hak menyusui, lembur dan pemutusan hubungan kerja karena alasan khusus. Setelah ditelisik lebih jauh maka hak ibadah tidak 
diatur dalam perundang-undangan. Namun, dari wawancara, peneliti memperoleh informasi bahwa para peerja di Kawasan Industri Makassar, berhak untuk beribadah sesuai agama dan keyakinannya masing-masing. Pada saat hari raya, mereka juga memperoleh bingkisan serta merayakannya dengan keluarga mereka. Pemberian kesempatan beribadah meskipun tidak di atur dalam perundang-undangan, umumnya diberikan kepada setiap pekerja. Kita hidup di Indonesia yang berdasarkan Pancasila dimana sila pertamanya adalah Ketuhanan Yang Maha Esa. Dalam sila ini ternisbatkan hak-hak setiap warga Negara untuk beribadah menurut keyakinannya masing-masing dimanapun di wilayah Indonesia.

Hak-hak untuk beribadah merupakan salah satu hak azasi manusia, hak-hak tersebut juga disadari oleh setiap pemilik perusahaan, sehingga mereka umumnya menyediakan tempat ibadah bagi pekerjanya; mushallah bagi pekerja muslim. Pengusaha wajib memberikan kesempatan yang secukupnya kepada pekerja/buruh untuk melaksanakan ibadah yang diwajibkan oleh agamanya (Pasal 80 UU No. 13 Tahun 2003 tentang Ketenagakerjaan). Jika pengusaha yang tidak memberikan kesempatan yang secukupnya kepada pekerja untuk melaksanakan ibadah yang diwajibkan oleh agamanya dikategorikan sebagai tindak pidana dan kejahatan. Pelanggaran ini dikenakan sanksi pidana penjara paling singkat 1 (tahun) dan paling lama 4 (empat) tahun dan/atau denda paling sedikit Rp/ 100.000 .000 (seratus juta rupiah) dan paling banyak Rp. 400.000 .000 (empat ratus juta) (Koran Perdjoeangan diakses 20 Februari 2019).

Menilik berbagai kenyataan di atas, nampaklah bahwa para pekerja memang diberi waktu untuk melaksanakan ibadah mereka, sehingga para pekerja dapat melaksanakan kewajiban mereka. Dengan melaksanakan kewajiban mereka, maka aqidah pekerja dapat terpelihara. Sebagaimana kita ketahui bahwa lingkup aqidah meliputi: Ilahiyat (ketuhanan), Nubuwwait (kenabian), Ruhaniyyat (kerohanian), Sam'iyya (masalah-masalah yang hanya didengar dari syarae). Dengan kebebasan melaksanakan ibadah oleh para pekerja, maka diharapkan aqidah mereka tetap terpelihara. Bekerja memang bukanlah kewajiban perempuan, namun di masa sekarang ini pekerja perempuan adalah pemandangan yang umum. Ada juga pekerjaan yang hasilnya lebih baik jika dilakukan oleh perempuan, karena mereka dianggap telaten. 
Meskipun demikian, mereka tetap harus memperhatikan keluarganya dan memelihara aqidahnya.

\section{KESIMPULAN}

Salah satu aspek penting transformasi struktur perekonomian Indonesia sepanjang era Orde Baru adalah peningkatan peranan sector industry yang tergolong sangat pesat. Meskipun sector-sektor lain juga pengalami pertumbuhan, namun pertumbuhannya cenderung lebih lamban daripada sector industry. Namun, dibalik pertumbuhan sector industry yang begitu pesat, ada permasalah serius yang mengancam sector industry itu sendiri yaitu kesenjangan. Terdapat kesenjangan antara industry besar dan menengah dengan industry kecil dan rumah tangga yang bisa dilihat secara jelas dengan membandingkan produktivitas relative keduanya. Produktifitas relative industry kecil dan rumah tangga hanya sekitar $10 \%$ produktivitas relative industry besar dan menengah.

Kebutuhan hidup yang semakin meningkat dan terkikisnya lahan-lahan agraris "memaksa" perempuan yang sejatinya hanya berkutat di rumah tangganya, harus bekerja mencari nafkah tambahan. Perempuan tidak hanya berperan pada reproduksi, tetapi juga mengambil bagian dalam produksi. Penelitian ini mengindikasikan bahwa meskipun perempuan Lantebung bekerja sebagai buruh pabrik, hal tersebut tidak menghalanginya untuk memberikan pendidikan aqidah kepada anak-anaknya. Bekerjanya mereka juga tidak menjadi penghalang untuk tetap menjaga aqidah mereka, karena pihak pabrik tetap memberikan waktu kepada mereka untuk beribadah, ada hari libut di hari raya, serta adapula yang diberi hadiah lebaran oleh pabrik tempatnya bekerja.

\section{IMPLIKASI PENELITIAN}

1. Diharapkan dengan penelitian ini menambah wawasan akan salah satu sisi pekerja perempuan, yakni menyangkut aqidahnya.

2. Penelitian ini juga dapat menambah referensi bagi para pengusaha tentang pentingnya memperhatikan kebutuhan ibadah para pekerjanya, agar dapat menambah dan memperbaiki produktivitas mereka. 


\section{DAFTAR PUSTAKA}

Baiquni M. 2009. Revolusi Industri, Ledakan Penduduk Dan Masalah Lingkungan. Jurnal Sains dan Teknologi Lingkungan Volume 1 No. 1 Januari 2009 ISSN: 2085-1227.

Bradshaw, Sarah., Castellino, Joshua and Diop, Bineta. 2013. Women's Role In Economic Development: Overcoming The Constraints. Background Paper For The High-Level Panel Of Eminent Persons On The Post-2015 Development Agenda on 20 May 2013.

Bungin, Burhan. Penelitian Kualitatif: Komunikasi, Ekonomi, Kebijakan Publik, dan Ilmu Sosial Lainnya. Edisi Kedua. Jakarta: Kencana Prenada Media Group, 2011.

Fodor, Eva And Horn, Daniel. 2015. Economic Development And Gender Equality: Explaining Variations In The Gender Poverty Gap After Socialism”. Institute Of Economics, Centre For Economic And Regional Studies, Hungarian Academy Of Sciences Budapest.

Garcia, Laura Cabeza., Brio, Esther B. Del and Victorio, Mery Luz Oscanoa. 2018. Gender Factors and Inclusive Economic Growth: The Silent Revolution. Journal. Sustainability 2018, 10, 121; doi:10.3390/su10010121

Hakim, Arif. No Date. Industrialisasi di Indonesia: Menuju Kemitraan yang Islami.

Marhumah. 2011. Konstruksi Gender, Hegemoni Kekuasaan, dan Lembaga Pendidikan. Karsa, Vol. 19 No. 2 Tahun 2011 (167 - 182).

Martini, Luh Kadek Budi. 2015. Peranan Perempuan Pada Pembangunan Ekonomi Dalam Perspektif Gender. Juima Vol. 5 No. 2, September 2015.

Mujahidah. 2010. Dinamika Gender Dan Peran Perempuan Dalam Ekonomi Keluarga. Pare-Pare. Jurnal Al- Ulum Volume. 10, Nomor 1, Juni 2010 Hal. 1-22.

Repository. radenintan.ac.id 